\title{
Photocatalytic Synthesis of Phenol by Direct Hydroxylation of Benzene by a Modified Nanoporous Silica (LUS-1) under Sunlight
}

\author{
Ghasem SHIRAVAND $^{1}$, Alireza BADIEI ${ }^{1,{ }^{*}}$, Ghodsi Mohammadi ZIARANI ${ }^{2}$, \\ Morteza JAFARABADI ${ }^{1}$, Majid HAMZEHLOO ${ }^{1}$ \\ ${ }^{1}$ School of Chemistry, College of Science, University of Tehran, Tehran, Iran \\ ${ }^{2}$ Department of Chemistry, Faculty of Science, Alzahra University, Tehran, Iran
}

\begin{abstract}
Fe-g- $\mathrm{C}_{3} \mathrm{~N}_{4}$-LUS-1 was prepared by the thermal decomposition of dicyandiamide inside the pores of LUS-1 under an inert atmosphere. It was used as a photocatalyst for the hydroxylation of benzene to phenol in sunlight. The catalysts were characterized by Fourier transform infrared spectroscopy, $\mathrm{N}_{2}$ adsorption-desorption, X-ray diffraction, and scanning electron microscopy. In Fe-g- $\mathrm{C}_{3} \mathrm{~N}_{4}$-LUS-1, a single layer of graphitic carbon nitride $\left(\mathrm{g}-\mathrm{C}_{3} \mathrm{~N}_{4}\right)$ was formed on the surface of LUS-1. The photocatalytic activity of the iron containing g- $\mathrm{C}_{3} \mathrm{~N}_{4}$ based catalysts was investigated, and the catalytic activity was remarkably enhanced when the reaction condition was changed from dark to sunlight. The best result was obtained with $20 \% \mathrm{Fe}-\mathrm{g}-\mathrm{C}_{3} \mathrm{~N}_{4}-\mathrm{LUS}-1$ in sunlight.
\end{abstract}

Key words: mesoporous silica; photocatalyst; phenol; benzene hydroxylation; sunlight; nanoporous silica; carbon nitride CLC number: O643 Document code: A

Received 21 January 2012. Accepted 30 May 2012.

*Corresponding author. Tel: +98-2161112614; Fax: +98-2161113301; E-mail: abadiei@khayam.ut.ac.ir

This work was supported by University of Tehran.

English edition available online at Elsevier ScienceDirect (http://www.sciencedirect.com/science/journal/18722067).

There is increasing interest in the photocatalytic technology in catalytic processes for hydrogen production from splitting water, self-cleaning coatings, high efficiency solar cells, and dye degradation [1-8]. These processes need considerable energy, and providing the energy is one of the most important issues. Many attempts have been made to find photocatalytic processes that utilize a renewable low cost irradiation source, such as sunlight, instead of expensive artificial irradiation sources [8-12]. Since visible light comprises a large portion of the solar energy reaching the surface of the earth, the utilization of visible light will give a more efficient solar energy usage. To achieve this, a material with a suitable band gap for absorbing visible light and that acts as an oxidative material is needed. Several materials, e.g., $\mathrm{Bi}_{38} \mathrm{ZnO}_{58}$ [13], $\mathrm{CuO}$ [14], $\mathrm{Au} / \mathrm{TiO}_{2}$ [15], $\mathrm{NiO} / \mathrm{InTaO}_{4}[16], \mathrm{BiVO}_{4}$ [17], and $\mathrm{g}_{-} \mathrm{C}_{3} \mathrm{~N}_{4}$ [3,18], have a suitable band gap for use in photocatalytic processes under visible light irradiation and in sunlight. The band gap of graphitic carbon nitride $\left(\mathrm{g}-\mathrm{C}_{3} \mathrm{~N}_{4}\right)$ was estimated to be $2.7 \mathrm{eV}$ from its UV-Vis diffuse reflectance spectrum [19], which is equal to $460 \mathrm{~nm}$ wavelength. As a result, g- $\mathrm{C}_{3} \mathrm{~N}_{4}$ can be used as a photocatalyst in the visible light region. There are several models for the structure of these compounds. The tri-s-triazine based model is the predicted most stable structure of $\mathrm{g}-\mathrm{C}_{3} \mathrm{~N}_{4}[20,21]$.

Several methods have been used to synthesize $\mathrm{g}-\mathrm{C}_{3} \mathrm{~N}_{4}$, e.g., by solid state reaction $[21,22]$, solvothermal reaction $[23,24]$, thermal decomposition [25], ionothermal reaction [26], and other methods [27-29]. Several precursors such as cyanamide, dicyandiamide, melamine, and cyanuric chloride have been used to get the $\mathrm{g}-\mathrm{C}_{3} \mathrm{~N}_{4}$ solid [28-31]. The easy sublimation of melamine is a serious issue in thermolysis. Dicyandiamide is recommended as a precursor to suppress this sublimation [20].

g- $\mathrm{C}_{3} \mathrm{~N}_{4}$ has been used as a photocatalyst in several reactions $[18,32,33]$. Chen et al. [18] investigated the catalytic performance of graphitic carbon nitride for the direct hydroxylation of benzene to phenol. They reported that benzene is adsorbed and activated on $\mathrm{g}_{-} \mathrm{C}_{3} \mathrm{~N}_{4}$, and therefore, this catalyst is a promising catalyst for the hydroxylation of benzene to phenol. In this work, graphitic carbon nitride was prepared and loaded on the surface of mesoporous Type LUS-1 silica. Due to its high surface area $\left(800 \mathrm{~cm}^{2} / \mathrm{g}\right)$, long range ordered pores (average pore diameter $3 \mathrm{~nm}$ ) and hydrothermal stability, LUS-1 is a good support for catalytic reactions such as the hydroxylation of benzene [34]. The hydroxylation of benzene to phenol over Fe-loaded mesoporous silica, such as SBA-15 or MCM-41, with different iron contents had been investigated previously $[35,36]$. In this study, the properties and applications of $x$ Fe-g- $\mathrm{C}_{3} \mathrm{~N}_{4}$ and $x$ Fe-g- $\mathrm{C}_{3} \mathrm{~N}_{4}$-LUS- 1 in the direct hydroxylation of benzene were studied. These reactions were carried 
in just under sunlight to study if they can be used to reduce cost.

\section{Experimental}

\subsection{Materials}

Silica gel (column chromatography), sodium hydroxide, dicyandiamide, iron(III) chloride hexahydrate, acetonitrile, benzene, toluene, hydrogen peroxide $(30 \%)$, and cetyltrimethylammonium bromide (Merck) and $p$-toluene-sulfonic acid monohydrate (Aldrich) of analytical grade were used without further purification.

\subsection{Characterization}

The catalysts were characterized by X-ray diffraction (XRD), Fourier transform infrared spectroscopy (FT-IR), scanning electron microscopy (SEM), and $\mathrm{N}_{2}$ adsorption-desorption. SEM was carried out on a Hitachi (model S-4160) apparatus after gold plating of the samples. XRD patterns were recorded with a Bruker D8-Advance diffractometer at $2 \theta=2^{\circ}-70^{\circ}$ with monochromatized $K_{\alpha}$ radiation $(\lambda=0.1541874 \mathrm{~nm})$ from a $\mathrm{Cu}$ source operated at $40 \mathrm{kV} / 30$ $\mathrm{mA}$. FT-IR spectra were obtained with an EQUINOX 55BRUKER. $\mathrm{N}_{2}$ adsorption-desorption isotherms were obtained using a BELSORP-mini II at $-196{ }^{\circ} \mathrm{C}$. All samples were degassed at $100{ }^{\circ} \mathrm{C}$ for $3 \mathrm{~h}$ under an inert gas flow before measurement. The BET equation was used to calculate specific surface area and the BJH equation was used to calculate the pore size distribution and total pore volume.

\subsection{Synthesis of catalysts}

\subsubsection{Synthesis of g- $\mathrm{C}_{3} \mathrm{~N}_{4}$ and Fe-g- $\mathrm{C}_{3} \mathrm{~N}_{4}$}

g- $\mathrm{C}_{3} \mathrm{~N}_{4}$ was prepared using the method reported by Wang et al. [18]. In a typical reaction, dicyandiamide (1 g) was mixed with distilled water $(10 \mathrm{ml})$ and heated to remove the solvent. The resulting mixture was heated at $600{ }^{\circ} \mathrm{C}$ for $4 \mathrm{~h}$ under flowing argon, followed by cooling to room temperature under the inert atmosphere. For the synthesis of Fe-g- $\mathrm{C}_{3} \mathrm{~N}_{4}$, different amounts of $\mathrm{FeCl}_{3} \cdot 6 \mathrm{H}_{2} \mathrm{O}(0.1,0.2,0.3$ $\mathrm{g})$ were added to the mixture of dicyandiamide $(1 \mathrm{~g})$ and distilled water $(10 \mathrm{ml})$, and then this solution was heated until a dry product was obtained. Different amounts of $\mathrm{FeCl}_{3}$ were loaded on $\mathrm{g}-\mathrm{C}_{3} \mathrm{~N}_{4}$ to obtain $x \mathrm{Fe}-\mathrm{g}-\mathrm{C}_{3} \mathrm{~N}_{4}(x=$ $10 \%, 20 \%, 30 \%)$.

\subsubsection{Synthesis of $x \mathrm{Fe}-\mathrm{g}-\mathrm{C}_{3} \mathrm{~N}_{4}$-LUS-1}

In a typical synthesis, LUS-1 (1 g, prepared using the method reported by Badiei et al. [37]) was dispersed in distilled water $(30 \mathrm{ml})$ with vigorous stirring (named mixture A). An amount of $\mathrm{FeCl}_{3} \cdot 6 \mathrm{H}_{2} \mathrm{O}$ and dicyandiamide were dissolved in distilled water $(30 \mathrm{ml})$ (iron(III) chloride/dicyandiamide $=0.1$, which was named solution $\mathrm{B}$. Solution B was gradually added to mixture A to prepare $x$ Fe-g- $\mathrm{C}_{3} \mathrm{~N}_{4}$-LUS-1 $(x(\mathrm{wt} \%)=$ [dicyandiamide/LUS-1] $\times$ $100 \%$ ). The mixture of solution A and solution B was heated at $100{ }^{\circ} \mathrm{C}$ to remove water until a reddish mixture was obtained. Finally, the product was obtained by heating the reddish material at $600{ }^{\circ} \mathrm{C}$ under an inert atmosphere for 4 h.

\subsubsection{Catalytic test}

Catalytic experiments were done to investigate the activity of the catalysts for the conversion of benzene to phenol. Solvent (4 $\mathrm{ml}$ acetonitrile) was poured into a $50 \mathrm{ml}$ round bottom flask equipped with a condenser and the temperature was raised to $60{ }^{\circ} \mathrm{C}$. Benzene $(1 \mathrm{ml}, 11.3 \mathrm{mmol})$ and well milled catalyst $(50 \mathrm{mg})$ were added to the flask. After $0.5 \mathrm{~h}$ stirring, hydrogen peroxide $\left(\mathrm{H}_{2} \mathrm{O}_{2} 30 \mathrm{wt} \%, 0.5 \mathrm{ml}, 16.5\right.$ mmol) was added to the mixture and the reaction mixture was stirred for $4 \mathrm{~h}$. Then, $5 \mathrm{ml}$ ethanol was poured into the flask to stop the reaction by capturing remaining hydroxyl radicals $(\mathrm{OH} \cdot)$ and convert the biphasic mixture into a single phase [38]. All reactions were carried out in dark and in sunlight (the sunlight reactions were done on sunny days with an intensity of about 80000 LUX) to evaluate the effect of light on the catalytic activity of $\mathrm{g}-\mathrm{C}_{3} \mathrm{~N}_{4}$. In addition, the photocatalytic activities of these catalysts were investigated using an artificial visible light source (125 W mercury lamp with an intensity about 67000 LUX with colored filter). The quantitative analysis of the product was done with a Perkin-Elmer 8500 GC with an FID detector and toluene as the internal standard.

\section{Result and discussion}

\subsection{XRD results}

Wide angle XRD patterns were used to characterize the structures of Fe-g- $\mathrm{C}_{3} \mathrm{~N}_{4}$, LUS-1, and Fe-g- $\mathrm{C}_{3} \mathrm{~N}_{4}$-LUS-1. The results are shown in Fig. 1. The predicted structure of g- $\mathrm{C}_{3} \mathrm{~N}_{4}$ based on tri-s-triazine building blocks (Franklin's model) would exhibit two major diffraction peaks in the XRD pattern corresponding to the (100) and (002) reflection planes $[20,26,33]$. Here, these peaks were observed in the XRD patterns of the synthesized materials (Fig. 1). This result proved that the synthesized $g-\mathrm{C}_{3} \mathrm{~N}_{4}$ structure was that predicted by Franklin's model [21,39]. As shown in Fig. 1(3), two peaks at $13.3^{\circ}$ and $27.4^{\circ}$ were seen, which were 

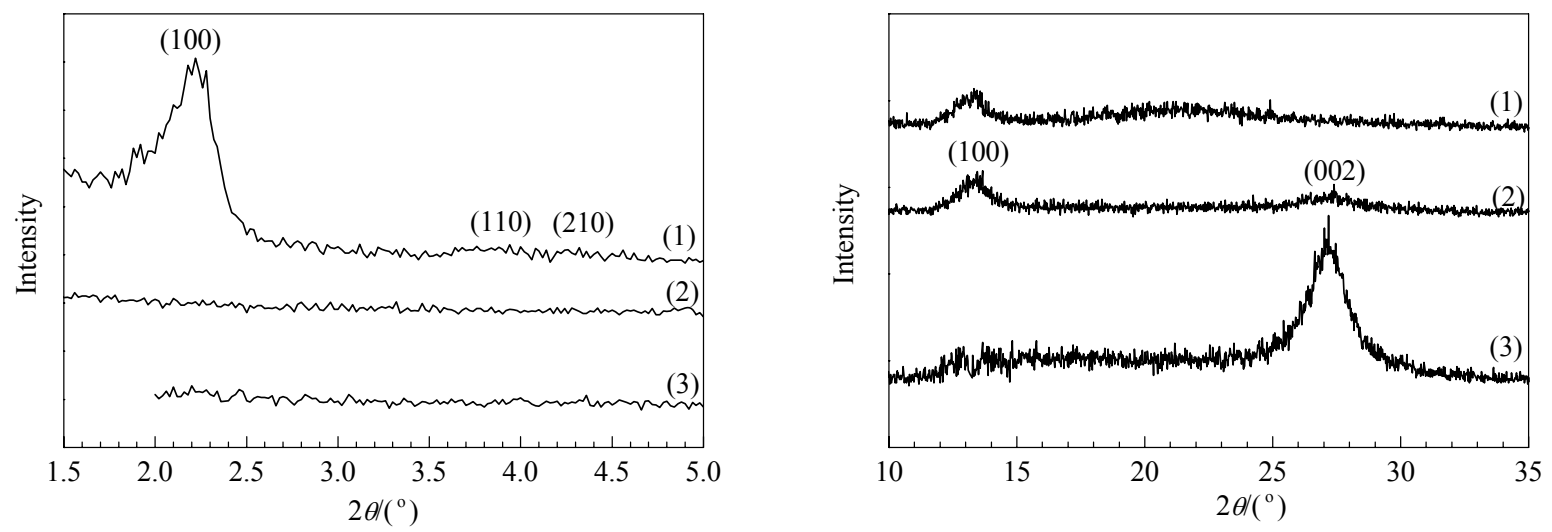

Fig. 1. XRD patterns of Fe-g- $\mathrm{C}_{3} \mathrm{~N}_{4}$-LUS-1 (1), Fe-g- $\mathrm{C}_{3} \mathrm{~N}_{4}(2)$, and $\mathrm{g}-\mathrm{C}_{3} \mathrm{~N}_{4}(3)$.

related to the hole-to-hole and interlayer distance of $\mathrm{g}-\mathrm{C}_{3} \mathrm{~N}_{4}$, respectively. The first peak was attributed to the in-plane structural packing of the carbon nitride layers. The peaks at $13.3^{\circ}$ and $27.4^{\circ}$ gave $d_{100}=0.665 \mathrm{~nm}$ and $d_{002}=0.326 \mathrm{~nm}$, respectively [33]. The XRD pattern of $\mathrm{Fe}-\mathrm{g}-\mathrm{C}_{3} \mathrm{~N}_{4}$ (Fig. 1(2)) showed similar peaks with a small shift and a significant decrease in the intensity for the latter peak $\left(27.4^{\circ}\right.$ to $\left.27.2^{\circ}\right)$. This observed shift in diffraction angle revealed that $d_{002}$ was increased to $0.328 \mathrm{~nm}$. In the case of the less intense $27.2^{\circ}$ diffraction, it was concluded that the introducing of the iron species into the $\mathrm{g}-\mathrm{C}_{3} \mathrm{~N}_{4}$ structure was successful, and this caused lower crystallinity and consequently lower diffraction intensity. From the increase in $d_{002}$ and decrease in $27.2^{\circ}$ peak intensity, it can be proposed that the iron species were loaded between the graphitic layers of carbon nitrides. With increasing Fe loading in $\mathrm{g}-\mathrm{C}_{3} \mathrm{~N}_{4}$, the crystallinity of Fe-g- $\mathrm{C}_{3} \mathrm{~N}_{4}$ decreased. Our results were in good agreement with those of other research groups [40].

The XRD pattern of Fe-g- $\mathrm{C}_{3} \mathrm{~N}_{4}$-LUS-1 is shown in Fig 1(1). This pattern showed the structural peaks of LUS-1 [34], which confirmed that the LUS-1 structure was retained. The comparison between the XRD patterns of g- $\mathrm{C}_{3} \mathrm{~N}_{4}$ and Fe-g- $\mathrm{C}_{3} \mathrm{~N}_{4}$-LUS-1 revealed the disappearance of the peak at $27.4^{\circ}$, but no change in the intensity of the other peak at $13.3^{\circ}$. With Fe-g- $\mathrm{C}_{3} \mathrm{~N}_{4}$, the (002) peak was not detected due to its very low intensity. In addition to other possibilities for the disappearance of the peak at $27.4^{\circ}$, another interesting structure can be suggested: it is a single layer of $\mathrm{g}-\mathrm{C}_{3} \mathrm{~N}_{4}$ formed in the pores of LUS-1. The complete understanding of this structure needs more studies.

\subsection{FT-IR results}

The FT-IR spectra of the samples are shown in Fig. 2. Figure 2(3)-(6) showed a strong absorption peak at 800 $\mathrm{cm}^{-1}$, which was attributed to the characteristic breathing mode of the triazine ring $[33,41]$. Usually, absorption peaks

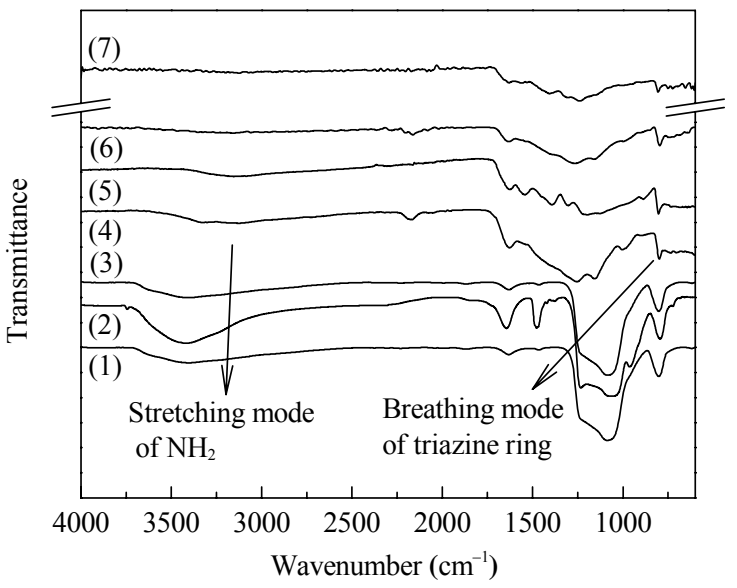

Fig. 2. FT-IR spectra of LUS-1 (1), 20\% Fe-g- $\mathrm{C}_{3} \mathrm{~N}_{4}-\mathrm{LUS}-1$ (2), $10 \%$ Fe-g- $\mathrm{C}_{3} \mathrm{~N}_{4}$-LUS-1 (3), g- $\mathrm{C}_{3} \mathrm{~N}_{4}$ (4), $10 \% \mathrm{Fe}-\mathrm{g}-\mathrm{C}_{3} \mathrm{~N}_{4}$ (5), $20 \% \mathrm{Fe}$-g$\mathrm{C}_{3} \mathrm{~N}_{4}(6)$, and $30 \% \mathrm{Fe}-\mathrm{g}-\mathrm{C}_{3} \mathrm{~N}_{4}(7)$.

due to the stretching mode of $\mathrm{C}-\mathrm{N}, \mathrm{C}=\mathrm{N}$, ring stretching and $\mathrm{N}-\mathrm{H}$ bending vibration in the heterocyclic aromatic ring system are observed as bands in the $1000-1700 \mathrm{~cm}^{-1}$ region $[23,24,31]$. The FT-IR spectra of $\mathrm{g}-\mathrm{C}_{3} \mathrm{~N}_{4}$ and Fe-g- $\mathrm{C}_{3} \mathrm{~N}_{4}$ showed these peaks. In the case of $x$ Fe-g- $\mathrm{C}_{3} \mathrm{~N}_{4}$-LUS- $1(x=$ $10 \%$ and $20 \%$ ), compounds containing $\mathrm{C}-\mathrm{N}$ and $\mathrm{C}=\mathrm{N}$ bonds were incorporated into the structure of the silica support LUS-1 (Fig. 2(1)) and the overlap of the strong broad peaks of $\mathrm{Si}-\mathrm{O}-\mathrm{Si}$ with these peaks makes it impossible to assign the $\mathrm{C}-\mathrm{N}$ and $\mathrm{C}=\mathrm{N}$ peaks in $\mathrm{Fe}-\mathrm{g}-\mathrm{C}_{3} \mathrm{~N}_{4}-\mathrm{LUS}-1$. In addition, the $\mathrm{C} \equiv \mathrm{N}$ stretching vibration was observed as a weak absorption peak appearing at $2200 \mathrm{~cm}^{-1}$ and the bands at $3000-3300 \mathrm{~cm}^{-1}$ can be assigned to the stretching mode of $\mathrm{NH}$ and $\mathrm{NH}_{2}$.

\section{$2.3 \quad \mathrm{~N}_{2}$ adsorption-desorption results}

The nitrogen adsorption-desorption isotherms for LUS-1 and Fe-g- $\mathrm{C}_{3} \mathrm{~N}_{4}$-LUS-1 are shown in Fig. 3. The LUS-1 material showed a Type IV isotherm that showed the presence 


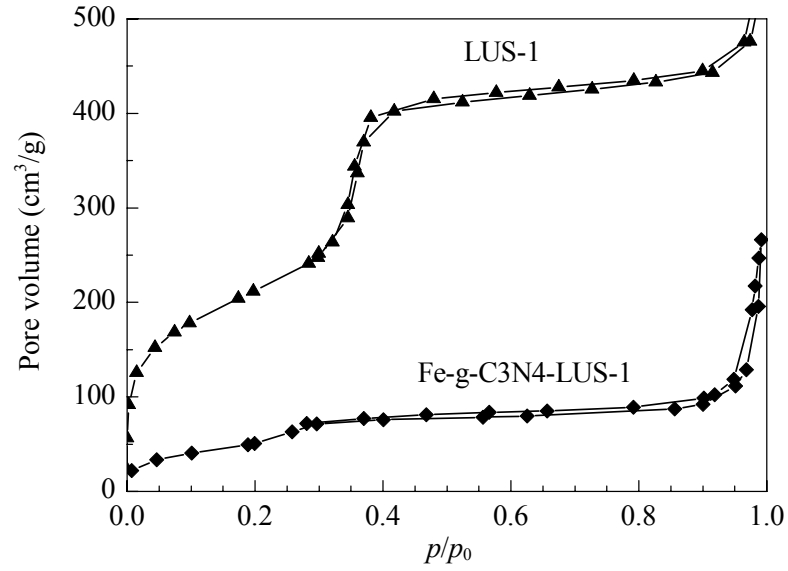

Fig. 3. $\mathrm{N}_{2}$ adsorption-desorption isotherms of LUS-1 and $10 \% \mathrm{Fe}-\mathrm{g}$ $\mathrm{C}_{3} \mathrm{~N}_{4}$-LUS-1.

of mesopores in this material (Fig. 3). On the other hand, the adsorption-desorption isotherm of $\mathrm{Fe}-\mathrm{g}-\mathrm{C}_{3} \mathrm{~N}_{4}$-LUS-1 was a deformed Type IV (Fig. 3) isotherm. It can be concluded that the introduction of $\mathrm{Fe}-\mathrm{g}-\mathrm{C}_{3} \mathrm{~N}_{4}$ into LUS-1 caused the surface area, average pore diameter, and pore volume of Fe-g- $\mathrm{C}_{3} \mathrm{~N}_{4}$-LUS-1 to be lower than those of LUS-1. From the data in Table 1, due to the loading of the graphitic carbon nitride in the pores of LUS-1, its surface area was decreased. In $30 \% \mathrm{Fe}-\mathrm{g}-\mathrm{C}_{3} \mathrm{~N}_{4}$-LUS- 1 , the pores of LUS-1 were blocked and the surface area was much decreased to $25 \mathrm{~m}^{2} / \mathrm{g}$. Therefore, $30 \% \mathrm{Fe}-\mathrm{g}-\mathrm{C}_{3} \mathrm{~N}_{4}$-LUS- 1 was not used in the reaction experiments. The structural parameters of these materials are shown in Table 1.

\subsection{SEM results}

SEM images of LUS-1 and Fe-g- $\mathrm{C}_{3} \mathrm{~N}_{4}$-LUS-1 are shown in Fig. 4. These SEM images gave the morphology of LUS-1 before and after $\mathrm{Fe}-\mathrm{g}-\mathrm{C}_{3} \mathrm{~N}_{4}$ loading. As the morphology of the Fe-g- $\mathrm{C}_{3} \mathrm{~N}_{4}$-LUS- 1 did not change during the reaction, it can be proposed that the morphology of the mesoporous silica was stable under the reaction conditions.
Table 1 Specific surface area, pore radius, and total pore volume of LUS- 1 and $x$ Fe-g- $\mathrm{C}_{3} \mathrm{~N}_{4}$-LUS- 1

\begin{tabular}{lccc}
\hline Sample & $\begin{array}{c}A_{\mathrm{BET}} / \\
\left(\mathrm{m}^{2} / \mathrm{g}\right)\end{array}$ & $\begin{array}{c}\text { Pore radius } \\
(\mathrm{nm})\end{array}$ & $\begin{array}{c}\text { Total pore volume } \\
\left(\mathrm{cm}^{3} / \mathrm{g}\right)\end{array}$ \\
\hline LUS-1 & 776 & 1.64 & 0.84 \\
Fe-g-C $\mathrm{N}_{4}$ & 10 & - & - \\
$10 \% \mathrm{Fe}-\mathrm{g}-\mathrm{C}_{3} \mathrm{~N}_{4}$-LUS-1 & 194 & 1.21 & 0.35 \\
$20 \% \mathrm{Fe}-\mathrm{g}-\mathrm{C}_{3} \mathrm{~N}_{4}$-LUS-1 & 149.3 & 1.21 & 0.31 \\
$30 \% \mathrm{Fe}-\mathrm{g}-\mathrm{C}_{3} \mathrm{~N}_{4}$-LUS-1 & 25 & - & - \\
\hline
\end{tabular}

\subsection{Catalytic activity}

The catalytic reaction results are shown in Fig. 5, Fig. 6 , Table 2, and Table 3 . The effects of various factors including the amount of $\mathrm{H}_{2} \mathrm{O}_{2}$, light source, and iron content on the hydroxylation of benzene to phenol were investigated.

\subsubsection{Effect of light source}

All reactions were done under both dark and sunlight conditions to investigate the effect of light on the reaction performance. From Table 2, the phenol yields in the dark were negligible compared with those in light. The catalytic performance was remarkably enhanced when the reaction condition was changed to be in sunlight. It can be suggested that $\mathrm{g}-\mathrm{C}_{3} \mathrm{~N}_{4}$ adsorbed sunlight and activated Fenton's reagent. In addition, the decomposition of $\mathrm{H}_{2} \mathrm{O}_{2}$ increased in the presence of sunlight and this produced more hydroxyl radicals. Hydroxyl radicals attack the benzene molecules and produce phenol and other hydroxylated species. To study the effect of an artificial light source on the reaction performance, a $\mathrm{Hg}$ lamp with a colored filter (violet filter) was used as a visible light source. The results of these experiments are also shown in Table 2 . When the added hydrogen peroxide was $0.5 \mathrm{ml}$, the phenol yields of $10 \% \mathrm{Fe}-\mathrm{g}-\mathrm{C}_{3} \mathrm{~N}_{4}$ were $5 \%$ and $5.6 \%$ for visible light and sunlight reactions, respectively. This observation indicated that the photocatalytic activity of these materials was ap-
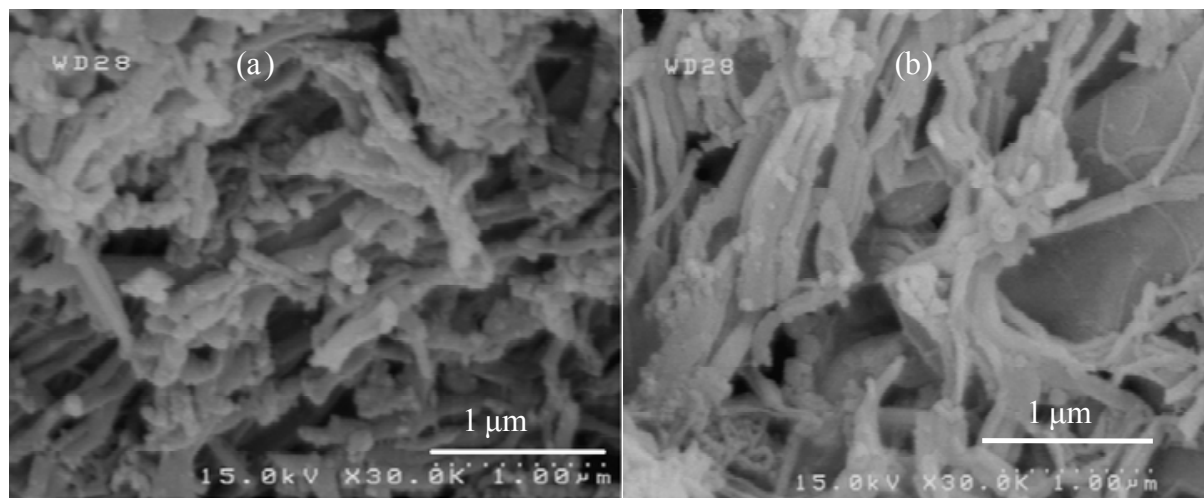

Fig. 4. SEM images of LUS-1 (a) and $10 \% \mathrm{Fe}-\mathrm{g}-\mathrm{C}_{3} \mathrm{~N}_{4}-\mathrm{LUS}-1$ (b). 


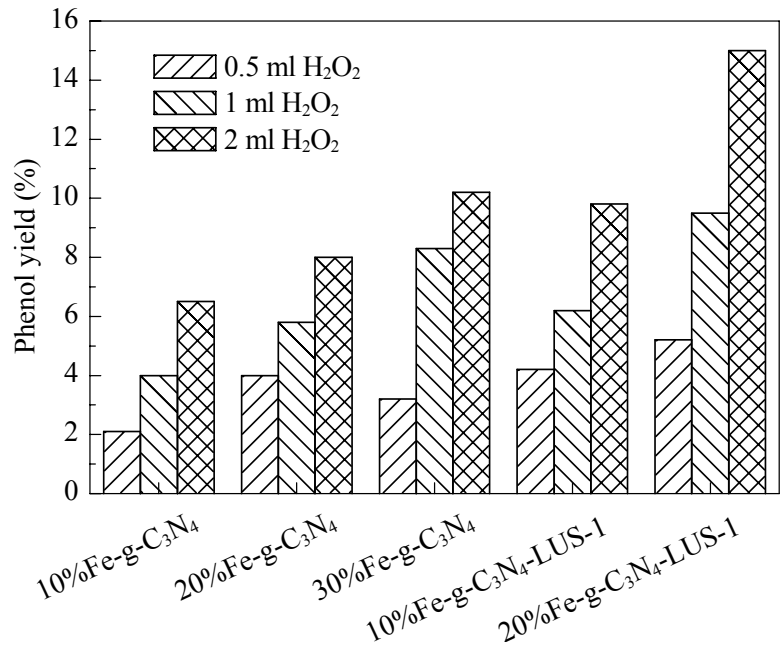

Fig. 5. Catalytic activity of g- $\mathrm{C}_{3} \mathrm{~N}_{4}$ based catalysts in the hydroxylation of benzene under sunlight in the presence of different amounts of $\mathrm{H}_{2} \mathrm{O}_{2}$. Reaction conditions: $1 \mathrm{ml}$ benzene, $4 \mathrm{ml}$ acetonitrile, $0.05 \mathrm{~g}$ catalyst, reaction temperature $60{ }^{\circ} \mathrm{C}$. Phenol yield was calculated according to the moles of produced phenol/moles of initial benzene.

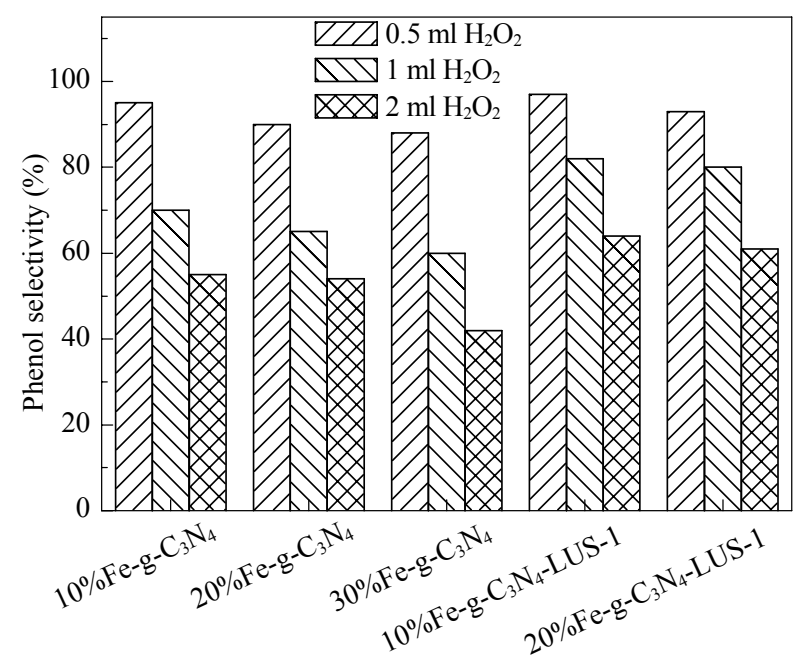

Fig. 6. Phenol selectivity of the catalysts in the presence of different amounts of $\mathrm{H}_{2} \mathrm{O}_{2}$ under sunlight. Reaction condition: $1 \mathrm{ml}$ benzene, 4 $\mathrm{ml}$ acetonitrile, $0.05 \mathrm{~g}$ catalyst, reaction temperature $60{ }^{\circ} \mathrm{C}$. Phenol selectivity was calculated according to the moles of produced phenol/moles of reacted benzene.

proximately similar for the two conditions. Thus, it can be suggested that the effect of the $125 \mathrm{~W} \mathrm{Hg}$ lamp and sunlight on the hydroxylation of benzene was similar. Therefore, all reactions were done in sunlight instead of the expensive artificial visible light source.
Table 3 TOF of the catalysts in the presence of different amounts of hydrogen peroxide under sunlight

\begin{tabular}{lccc}
\hline \multirow{2}{*}{ Sample } & \multicolumn{3}{c}{$\mathrm{TOF}\left(10^{2} \mathrm{~h}^{-1}\right)$} \\
\cline { 2 - 4 } & $0.5 \mathrm{ml}$ & $1 \mathrm{ml}$ & $2 \mathrm{ml}$ \\
\hline $10 \%$ Fe-g-C $\mathrm{C}_{4}$ & 23.7 & 45.2 & 73.4 \\
$20 \%$ Fe-g-C $\mathrm{C}_{3} \mathrm{~N}_{4}$ & 49.1 & 71.2 & 98.3 \\
$30 \%$ Fe-g-C $\mathrm{C}_{3} \mathrm{~N}_{4}$ & 67.2 & 112 & 137.2 \\
$10 \%$ Fe-g-C $\mathrm{C}_{3} \mathrm{~N}_{4}$-LUS-1 & 674 & 942 & 1570 \\
$20 \%$ Fe-g-C C $\mathrm{N}_{4}$-LUS-1 & 479 & 856 & 1370 \\
\hline
\end{tabular}

\subsubsection{Effect of $\mathrm{H}_{2} \mathrm{O}_{2}$}

When the amount of hydrogen peroxide was increased from 0.5 to $2 \mathrm{ml}$, the phenol yield increased from $2.1 \%$ to $6.5 \%$ for $10 \% \mathrm{Fe}-\mathrm{g}-\mathrm{C}_{3} \mathrm{~N}_{4}, 4 \%$ to $8 \%$ for $20 \% \mathrm{Fe}-\mathrm{g}-\mathrm{C}_{3} \mathrm{~N}_{4}$, and $5 \%$ to $10.2 \%$ for $30 \% \mathrm{Fe}-\mathrm{g}-\mathrm{C}_{3} \mathrm{~N}_{4}$. The increase in phenol yield in the presence of more hydrogen peroxide was attributed to the increase of hydroxyl radicals in the reaction mixture, which attack benzene rings and produce more hydroxylated species of benzene. However, the use of more hydrogen peroxide resulted in less phenol selectivity. Side reactions occurred when hydroxyl radicals were added, and these produced other hydroxylated species of benzene such as catechol, benzoquinone, etc.

\subsubsection{Effect of iron content}

To evaluate the effect of iron loading on the hydroxylation of benzene, graphitic carbon nitride $\left(\mathrm{g}-\mathrm{C}_{3} \mathrm{~N}_{4}\right)$ with different amounts of iron content was synthesized. When the iron content was increased, the phenol yield was enhanced. For example, when the added hydrogen peroxide was $2 \mathrm{ml}$, the phenol yield was increased from $6.5 \%$ to $10.5 \%$ for $10 \%$ Fe-g- $\mathrm{C}_{3} \mathrm{~N}_{4}$ and $30 \%$ Fe-g- $\mathrm{C}_{3} \mathrm{~N}_{4}$, respectively. This observation and the mechanism (Fenton's reaction) of benzene hydroxylation were useful for interpreting the effect of iron content on the hydroxylation reaction. Briefly, the presence of more active iron species in the reaction mixture gave more of the necessary hydroxyl radicals. Thus, more benzene molecules were converted to the hydroxylated form.

\subsubsection{Comparison of unsupported and supported catalysts}

The effect of using a support on the reaction was investi-

Table 2 Phenol yield (\%) of Fe-g- $\mathrm{C}_{3} \mathrm{~N}_{4}$ under sunlight and visible light conditions in the presence of different amount of $\mathrm{H}_{2} \mathrm{O}_{2}$

\begin{tabular}{|c|c|c|c|c|c|c|}
\hline \multirow{2}{*}{ Sample } & \multicolumn{3}{|c|}{$0.5 \mathrm{ml} \mathrm{H}_{2} \mathrm{O}_{2}$} & \multicolumn{3}{|c|}{$2 \mathrm{ml} \mathrm{H}_{2} \mathrm{O}_{2}$} \\
\hline & Dark & Sunlight & Visible light & Dark & Sunlight & Visible light \\
\hline $10 \% \mathrm{Fe}-\mathrm{g}-\mathrm{C}_{3} \mathrm{~N}_{4}-\mathrm{LUS}-1$ & 0.8 & 4.3 & 4 & 2.1 & 10 & 9.8 \\
\hline $20 \% \mathrm{Fe}-\mathrm{g}-\mathrm{C}_{3} \mathrm{~N}_{4}$-LUS-1 & 1.8 & 5.6 & 5 & 4.7 & 16 & 15.6 \\
\hline
\end{tabular}

The phenol yield was calculated according to produced phenol/initial benzene. 
gated. The results are shown in Figs. 5 and 6. For this comparison, mesoporous LUS-1 was used as a porous support and different amounts of $x \mathrm{Fe}-\mathrm{g}-\mathrm{C}_{3} \mathrm{~N}_{4}$ were incorporated into it $(x=10 \%, 20 \%)$. When the amount of added hydrogen peroxide was $2 \mathrm{ml}$, the phenol yield was increased from $8 \%$ to $16 \%$ by loading $20 \%$ Fe-g- $\mathrm{C}_{3} \mathrm{~N}_{4}$ on the surface of LUS- 1 . This result showed that the catalytic activity of graphitic carbon nitride was remarkably enhanced by using a support. In addition, it can be seen in Fig. 6 that on adding more $\mathrm{H}_{2} \mathrm{O}_{2}$, the selectivity for phenol decreased with both supported and unsupported catalysts. However, a smaller decrease in phenol selectivity was observed when the supported catalyst was used. From these results, it can be suggested that LUS-1 stabilized the phenol produced and protected it from more oxidation.

\subsubsection{Investigation of TOF}

The effects of various parameters on the turnover frequency (TOF) in the hydroxylation of benzene are shown in Table 3. The TOF was defined as moles of produced phenol per melem unit per hour. The TOF was increased by adding hydrogen peroxide into the reaction mixtures. In addition, with unsupported catalysts, the TOF was enhanced by increasing the iron loading. With these catalysts, increasing iron loading gave increased phenol yield at approximately a constant amount of melem units. However, with the supported catalysts, by increasing the amount of $\mathrm{g}-\mathrm{C}_{3} \mathrm{~N}_{4}$ in LUS-1, the TOF was decreased. In these reactions, the enhancing of produced phenols was negligible with increasing melem units.

\section{Conclusions}

g- $\mathrm{C}_{3} \mathrm{~N}_{4}, x$-Fe-g- $\mathrm{C}_{3} \mathrm{~N}_{4}$ and $x$-Fe-g- $\mathrm{C}_{3} \mathrm{~N}_{4}$-LUS-1 were prepared and characterized by XRD, FT-IR, $\mathrm{N}_{2}$ adsorption. and SEM. Their catalytic activity for the hydroxylation of benzene was investigated. The catalytic activity of Fe-g- $\mathrm{C}_{3} \mathrm{~N}_{4}$ was remarkably increased from dark to sunlight reaction conditions. The phenol yield increased on increasing either the amount of hydrogen peroxide or iron loading. The phenol selectivity was increased by loading $\mathrm{Fe}-\mathrm{g}-\mathrm{C}_{3} \mathrm{~N}_{4}$ in LUS-1. g- $\mathrm{C}_{3} \mathrm{~N}_{4}$ can be used as a photocatalyst in sunlight and does not need an expensive artificial light source.

\section{References}

1 Pan J H, Dou H, Xiong Z, Xu C, Ma J, Zhao X S. J Mater Chem, 2010, 20: 451

2 Wang J, Li R, Zhang Z, Sun W, Xu R, Xie Y, Xing Z, Zhang X. Appl Catal A, 2008, 334: 227

3 Goettmann F, Fischer A, Antonietti M, Thomas A. New $J$
Chem, 2007, 31: 1455

4 Pan H, Li X, Zhuang Z, Zhang C. J Mol Catal A, 2011, 345: 90

5 Sun J H, Dong S Y, Feng J L, Yin X J, Zhao X C. J Mol Catal A, 2011, 335: 145

6 Li K, Martin D, Tang J. Chin J Catal, 2011, 32: 879

7 Oh W-C, Chen M, Cho K, Kim C, Meng Z, Zhu L. Chin J Catal, 2011, 32: 1577

8 Xiao Y, Dang L, An L, Bai S, Lei Z. Chin J Catal, 2008, 29: 31

9 Ao Y, Xu J, Zhang S, Fu D. J Phys Chem Solids, 2009, 70: 1042

10 Guan G, Kida T, Yoshida A. Appl Catal B, 2003, 41: 387

11 Kuai L, Geng B, Chen X, Zhao Y, Luo Y. Langmuir, 2010, 26: 18723

12 Vidya K, Kamble V S, Selvam P, Gupta N M. Appl Catal B, 2004, 54: 145

13 Hou L-R, Yuan C-Z, Peng Y. J Mol Catal A, 2006, 252: 132

14 Nezamzadeh-Ejhieh A, Hushmandrad S. Appl Catal A, 2010, 388: 149

15 Sonawane R S, Dongare M K. J Mol Catal A, 2006, 243: 68

16 Wang Z-Y, Chou H-C, Wu J C S, Tsai D P, Mul G. Appl Catal A, 2010, 380: 172

17 Ke D, Peng T, Ma L, Cai P, Jiang P. Appl Catal A, 2008, 350: 111

18 Chen X, Zhang J, Fu X, Antonietti M, Wang X. J Am Chem Soc, 2009, 131: 11658

19 Zhang J, Chen X, Takanabe K, Maeda K, Domen K, Epping J D, Fu X, Antonieta M, Wang X. Angew Chem, Int Ed, 2010, 49: 441

20 Thomas A, Fischer A, Goettmann F, Antonietti M, Müller J O, Schlögl R, Carlsson J M. J Mater Chem, 2008, 18: 4893

21 Komatsu T. J Mater Chem, 2001, 11: 799

22 Komatsu T. Macromol Chem Phys, 2001, 202: 19

23 Zhang Z, Leinenweber K, Bauer M, Garvie L A J, McMillan P F, Wolf G H. J Am Chem Soc, 2001, 123: 7788

24 Guo Q, Xie Y, Wang X, Lv S, Hou T, Liu X. Chem Phys Lett, 2003, 380: 84

25 Montigaud H, Tanguy B, Demazeau G, Alves I, Courjault S. $J$ Mater Sci, 2000, 35: 2547

26 Lotsch B V, Schnick W. Chem Mater, 2006, 18: 1891

27 Bojdys M J, Müller J O, Antonietti M, Thomas A. Chem Eur J, 2008, 14: 8177

28 Montigaud H, Tanguy B, Demazeau G, Alves I, Birot M, Dunogues J. Diamond Relat Mater, 1999, 8: 1707

29 Bai Y J, Lü B, Liu Z G, Li L, Cui D L, Xu X G, Wang Q L. J Cryst Growth, 2003, 247: 505

30 Zhao H, Chen X L, Jia C, Zhou T, Qu X, Jian J, Xu Y. Mater Sci Eng B, 2005, 122: 226

31 Li X, Zhang J, Shen L, Ma Y, Lei W, Cui Q, Zou G. Appl Phys $A, 2009,94: 387$

32 Yan S C, Li Z S, Zou Z G. Langmuir, 2010, 26: 3894

33 Yan S C, Li Z S, Zou Z G. Langmuir, 2009, 25: 10397

34 Gholami J, Badiei A, Abbasi A, Ziarani G M. Int J ChemTech Res, 2009, 1: 426 
35 Martínez F, Calleja G, Melero J A, Molina R. Appl Catal B, 2005, 60: 181

36 Sirotin S V, Moskovskaya I F. Petrol Chem, 2009, 49: 99

37 Badiei A, Bonneviot L, Crowther N, Mohammadi Ziarani G. $J$ Organomet Chem, 2006, 691: 5911

38 Arab P, Badiei A, Koolivand A, Mohammadi Ziarani G. Chin J
Catal, 2011, 32: 258

39 Franklin E C. J Am Chem Soc, 1922, 44: 486

40 Wang X, Chen X, Thomas A, Fu X, Antonietti M. Adv Mater, 2009, 21: 1609

41 Guo Q, Xie Y, Wang X, Zhang S, Hou T, Lv S. Chem Commun, 2004: 26

\section{《催化学报》2011 年 SCI 影响因子首次突破 1.0}

根据美国汤森路透 (Thomson Reuters) 2012 年 6 月 29 日公布的 2011 年度《期刊引证报告》 (Journal Citation Reports, JCR), 《催化学报》 2011 年 SCI 影响因子首次突破 1.0, 达到 1.171, 总被引频次为 1529,5 年影响因子为 0.945 . 其中, 影响因子和 5 年影响因子均位居 SCI 收录的中文化学类期刊第 1 名, 也是历年来我国中文化学类期刊 SCI 影响 因子的最高值. 这表明, 《催化学报》正在被越来越多的国内外同行阅读和参考, 该刊在国际学术交流中的作用进一步 提高. 《催化学报》取得的成绩离不开广大作者、审稿专家和读者多年来的大力支持和帮助, 在此向您表示衷心感谢!

\section{Impact Factor of Chinese Journal of Catalysis is 1.171}

According to the 2011 Journal Citation Reports (JCR) published by Thomson Reuters, the impact factor of Chinese Journal of Catalysis reached 1.171, which is $56 \%$ higher than the previous year. This has been the highest SCI impact factor of Chinese Journal of Catalysis since she was included in the Science Citation Index-Expanded (SCI-E) in 2001, indicating that the Journal is now read and referred by more and more readers in the world. 